Article

\title{
A Study of the Relations between Soil Moisture, Soil Temperatures and Surface Temperatures Using ARM Observations and Offline CLM4 Simulations
}

\author{
Menglin S. Jin * and Terrence Mullens \\ Department of Meteorology and Climate Science, San José State University, San José, CA 95192, \\ USA; E-Mail: terrence.mullens@gmail.com \\ * Author to whom correspondence should be addressed; E-Mail: menglin.jin@sjsu.edu; \\ $+1-408-924-7331$.
}

External Editor: Nicole Mölders

Received: 10 January 2014; in revised form: 3 September 2014 / Accepted: 5 September 2014 / Published: 29 September 2014

\begin{abstract}
Soil temperature, soil moisture, skin temperature and 2-m air temperature are examined from both ground observations and the offline community land model (CLM4). Two-layer soil moisture and three-layer soil temperature observations from six-year (2003-2008) ground measurements at the Lamont, Oklahoma site supported by the Atmospheric Radiation Measurement (ARM) Program of the Department of Energy (DOE) show clear vertical and temporal relations between soil temperature and soil moisture with surface skin temperature and 2-m air temperature. First, daily means reveal that all of these variables have clear seasonal variations, with temperatures peaking in summer and minimizing in winter as a result of surface insolation. Nevertheless, the 2-m air temperature and upper soil temperature $(-0.05 \mathrm{~m})$ peak at $2 \mathrm{~h}$ after that of surface skin temperature because of the lag of transport of heat from the skin level to the $2-\mathrm{m}$ air and to underground respectively. As a result of such lag, at the monthly annual cycle scale, 2-m air temperature has higher correlation with upper soil temperature than skin temperature does. Second, there are little diurnal and annual variations at the lowest soil layer $(-0.25$ $\mathrm{m})$. Third, a negative correlation $(\sim-0.40)$ between skin temperature and soil moisture is observed, consistent with the expectation that heat flux and evaporation are competing physical processes for redistributing surface net radiation. Soil moisture, however, minimizes in March and maximizes in winter due to the local rainfall cycle. All of these key observed relations are qualitatively reproduced in the offline CLM4 using the
\end{abstract}


atmosphere forcing derived from ARM observations. Nevertheless, CLM4 is too dry at the upper layer and has less variation at the lower layer than observed. In addition, CLM4 shows stronger correlation between $\mathrm{T}_{\text {soil }}$ and $\mathrm{T}_{\text {skin }}(r=0.96)$ than the observations $(r=$ 0.64 ), while the predicted nighttime $\mathrm{T}_{\text {skin }}$ is $0.5-2{ }^{\circ} \mathrm{C}$ higher than the observations.

Keywords: land surface climatology; climate modeling; soil moisture; surface temperature; land surface model; ground observations

\section{Introduction}

Soil moisture is the quantitative water content in terms of volume (volumetric) or mass (gravimetric) among soil probes. This variable determines various key soil thermodynamic properties, such as heat conductivity, hydroconductivity, and the Bowen ratio. Therefore, soil moisture interacts with soil temperature, skin temperature, and air temperature in controlling the exchange of water and heat energy between the land surface and the atmosphere through evaporation and plant transpiration. Because the land model has a relatively long memory on soil moisture [1], reasonably simulating this variable is essential [2]. However, previous studies have shown that soil moisture has a positive feedback on precipitation patterns $[3,4]$ and various other physical processes such as surface humidity, surface insolation, snowmelt, and runoff [5-8]. In order to improve climate models, the relations between soil moisture and soil temperature need be further studied.

Soil moisture measurement is a challenge, in particular, from satellite measurements and at the global scale. Although remote sensing now can measure many land surface variables, such as vegetation and snow coverage [9-11], soil moisture information is still difficult to obtain from space due to the lack of a convincing remote sensing approach. Consequently, the relations among soil moisture, soil temperature, skin temperature, and air temperature are not well understood $[4,12]$. Probably at this stage, the most practical approach is to analyze the temporal variations of soil moisture and soil temperature from ground sites, study the vertical distributions of these variables, and reveal their relations with atmosphere and land surface processes.

Six-year instantaneous ground observations of land surface skin temperature $\left(\mathrm{T}_{\text {skin }}\right)$, which is the radiometric temperature derived from surface upward longwave emission, is closely related to land surface radiative properties $[13,14] . \mathrm{T}_{\text {skin }}$ and 2-m surface air temperature $\left(\mathrm{T}_{\text {air }}\right)$ are both important variables at land surface with different physical meaning and magnitude [15]. $\mathrm{T}_{\text {skin }}, \mathrm{T}_{\text {air }}$, upper soil temperature $\left(\mathrm{T}_{\text {soil }}\right)$ at $0.05 \mathrm{~m}$ below ground, middle $\mathrm{T}_{\text {soil }}$ at $0.15 \mathrm{~m}$ below ground, lower $\mathrm{T}_{\text {soil }}$ at $0.25 \mathrm{~m}$ below ground, upper soil moisture and lower soil moisture monitored at the Lamont, Oklahoma Atmospheric Radiation Measurement (ARM) Program of Department of Energy (DOE) site are used to examine the diurnal, seasonal, and vertical relations among these variables. Specifically, the goals of this work are to:

(a) understand the vertical and temporal variations of volumetric water content;

(b) understand the relations among soil moisture, soil temperature and surface temperature based on long-duration ground observations; 
(c) evaluate the CLM4 simulations with respect to the relations identified in (b).

Section 2 provides data and modeling information. Results are presented in Section 3 in two parts; part 1 is AMR observations and part 2 is offline CLM4 simulations. Final discussions and remarks are given in Section 4.

\section{ARM Data and Offline Community Land Model Simulations}

\subsection{ARM Data}

Since 1992, the U.S. Department of Energy (DOE) Atmospheric Radiation Measurement Program (ARM) has built six ARM Climate Research Facilities (ACRF) to continuously measure atmospheric, land, and soil variables. The Lamont, Oklahoma site $\left(36^{\circ} 36^{\prime} 18.0^{\prime \prime} \mathrm{N}, 97^{\circ} 29^{\prime} 6.0^{\prime \prime} \mathrm{W}\right.$, altitude $\left.320 \mathrm{~m}\right)$ is one of the ACRF sites analyzed in this paper. Land cover of this site is winter [16] or cropland according to MODIS land cover observation.

Soil moisture and temperature are monitored by the Carbon Dioxide Flux Measurement Systems (CO2FLX, [16]. Volumetric soil moisture content is continuously measured using four replicate soil impedance probes (Delta-T, ML2x) at two depths $(-0.05$ and $-0.25 \mathrm{~m}$, within an effective sampling interval of $\sim 5 \mathrm{~cm}$ ) with an accuracy of $0.05 \mathrm{~cm}^{3} \cdot \mathrm{cm}^{-3}$ estimated by the manufacturer for the case of un-calibrated soils. Soil temperature is measured with four replicate thermocouple probes at three depths $(-0.05,-0.15$, and $-0.25 \mathrm{~m})$ with an accuracy of approximately $0.5 \mathrm{~K}$. It should be noted that the agricultural soil is periodically disturbed by field management, leaving an uneven surface layer that introduces heterogeneity into the placement of the shallow probes. All soil data are averaged to half hour intervals for each depth and sensor type for later analysis. Data was also averaged to daily and monthly in this analysis. 2003-2008 data are used to represent the climatological sense of soil moisture and temperature for that region.

$\mathrm{T}_{\text {skin }}$ measurement is calculated from surface upwelling $(10 \mathrm{~m})$ longwave hemispheric irradiance. Specifically, this data is from the Quality Control of Radiation (QCRAD) value-added product. It has an original temperature resolution of $1 \mathrm{~min}$, and an averaging interval of $1 \mathrm{~h}$.

There were some missing days of data. For example, in 2004, soil temperature was available for 251 of the 366 days. As a result, soil moisture was only compared to $\mathrm{T}_{\text {skin }}$ on days when both were available (270 for lower, 297 for upper).

\subsection{Offline CLM4 Simulations}

The Offline Community Land Model (CLM4) [17], which is the land scheme coupled into the Community Earth System Model (CESM) developed at the National Center for Atmospheric Research (NCAR), is examined using ARM-Lamont atmospheric forcing and evaluation data set for year 2004. This paper focuses on evaluating skin temperature, soil temperature and soil moisture analyses because little research has focused on temperature and moisture relations in CLM4. We find that CLM4 simulates skin temperature well in Spring and Fall, but overestimates it in Summer and Winter, by up to $2.8^{\circ} \mathrm{C}$ at daily average. In addition, CLM4 is too dry at the upper layer $(-0.05 \mathrm{~m})$ and lower layer $(-0.25 \mathrm{~m})$. Nevertheless, a large deficiency occurs for snow coverage and consequently albedo simulation in winter. 
The CLM4 control simulation is driven by the default offline forcing, which is extracted from NCAR/NCEP reanalysis and provided in CESM model release [18,19], for the one-point (Lamont OK). The sensitivity run (case CLM4-arm-forcing) is forced by the ARM observations taken at the same location in order to reduce the model uncertainties induced by the atmosphere forcing. Specifically, the offline CLM4 is forced using hourly ARM observed direct and diffuse surface solar radiation, wind, precipitation, downward longwave radiation, humidity and 2-m $\mathrm{T}_{\text {air. Hourly }}$ observation data set (ARM-OK) for land model forcing as well as evaluation is developed from the Oklahoma Lamont site (e.g., CO2flx site) from ARM program. This ARM-OK data set has two parts: forcing data (e.g., ARM-OK-forcing) and evaluation data (e.g., ARM-OK-evaluation). ARM-OK-forcing includes direct and diffusive solar radiation, downward longwave radiation, air temperature, precipitation, wind speed and direction which are needed to force offline land surface model. ARM-OK-evaluation, on the other hand, includes $2-\mathrm{m}$ temperature, $\mathrm{T}_{\text {skin, }}$ upward longwave radiation, ground flux, two layers of soil temperature, three layers of soil temperature, and $\mathrm{CO}_{2}$ flux. ARM-OK forcing is used to run offline Community Land). A report on how ARM missing data is treated is currently under review [20]. Furthermore, the offline CLM4 run has a 50 year spin up with soil moisture initialized using ARM observations.

Observations during the year 2004 are randomly selected to force the offline CLM4 simulations and then to evaluate the outputs to demonstrate the performance of CLM4 $\mathrm{T}_{\text {skin, }}$, soil temperature and soil moisture relations. Other years, such as 2003 and 2005, are also simulated, and the results are consistent with those presented for 2004.

\section{Results}

\subsection{ARM Observations}

The diurnal cycle is evident on upper soil moisture in both January and July 2004 (Figure 1). For July, the soil moisture minimum occurred at 03:00 and maximum is at 12:00, before minimum and maximum temperatures. On the other hand, the January minimum daily soil moisture occurred at 10:00, after the minimum air and skin temperatures. Furthermore, the July soil moisture diurnal cycle is less smooth than January, partly because of some missing days of data for July ( $28 \mathrm{~h}$ of missing data for $\mathrm{T}_{\text {skin, }} 22 \mathrm{~h}$ of missing data for $\mathrm{T}_{\text {air }}, 193 \mathrm{~h}$ of missing data for the average of upper and lower soil moisture, or about 8 days). Nevertheless, the primary reason for the July cycle being less smooth is precipitation events during this period of time. In addition, the soil moisture is higher in January, with less monthly variation in January, than in July.

Surface $\mathrm{T}_{\text {skin }}$ and 2-m $\mathrm{T}_{\text {air }}$ have clear diurnal cycles that follow surface insolation; namely, lowest in the early morning just before sunrise and highest at local noon. Also, due to radiative cooling at night, $\mathrm{T}_{\text {skin }}$ is lower than $\mathrm{T}_{\text {air }}$ during the night and then increases due to absorption of ground energy during the day. In addition, $\mathrm{T}_{\text {skin }}$ is higher than $\mathrm{T}_{\text {air }}$ during most of the day. A similar pattern also occurs in July with the largest difference between $\mathrm{T}_{\text {skin }}$ and $\mathrm{T}_{\text {air }}$ at noon of about $3.0^{\circ} \mathrm{C}$. Such a pattern is typical and is consistent with the earlier observations in other field experiments such as FIFE [13]; namely, $\mathrm{T}_{\text {skin }}$ is higher than $\mathrm{T}_{\text {air }}$ during daytime (09:00-16:00) but lower than $\mathrm{T}_{\text {air }}$ at night and early morning, before the surface heats up by absorbing surface insolation. Other years of ARM observations during 
2000-2008 are also examined (not shown) and the temperature patterns are very similar, except that July soil moisture is largely dependent on local time and rainfall occurrence. Jin and Dickinson have proved that such a typical pattern is a function of land cover, latitude, and cloud conditions [14].

Figure 1. Monthly mean diurnal cycle of skin temperature (Tskin), upper-layer soil moisture, and 2-m air temperature (Tair) for (a) January 2004; (b) July 2004. Data is from Atmospheric Radiation Measurement (ARM) Lamont, OK site.

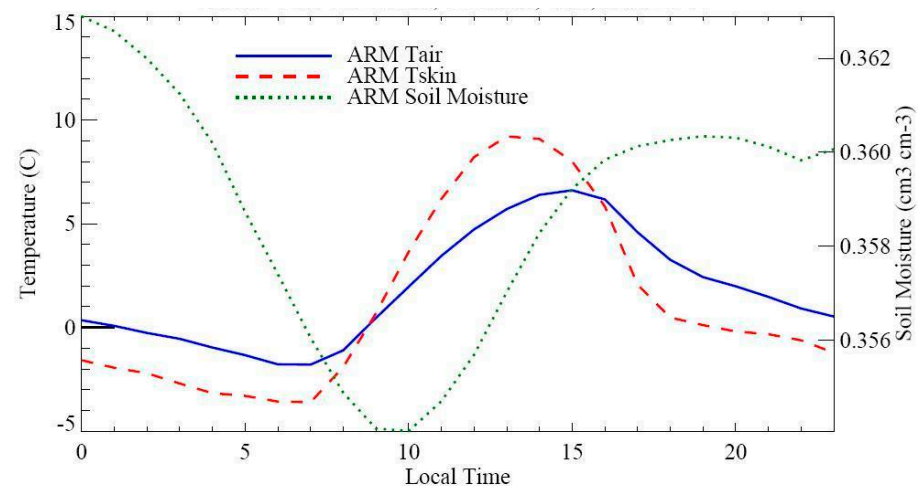

(a)

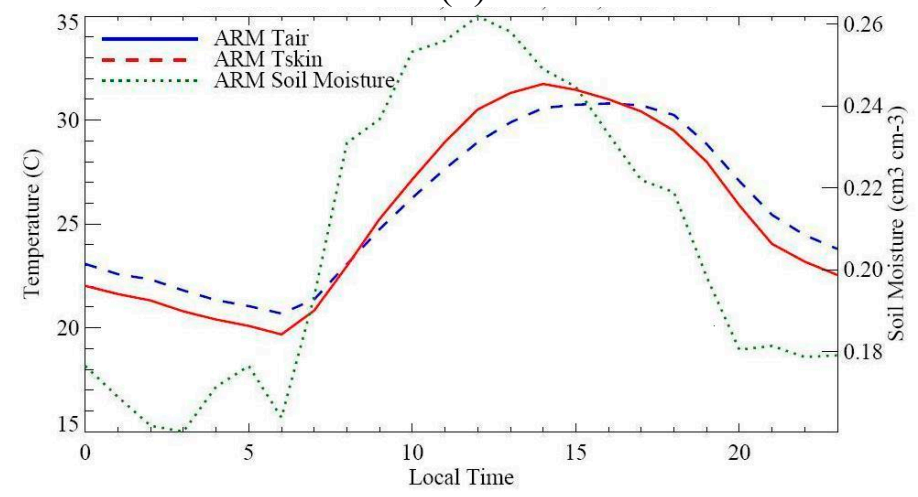

(b)

Due to evaporation at the upper soil level $(-0.05 \mathrm{~m})$, soil moisture is generally about $0.1 \sim 0.2 \mathrm{~cm}^{3} \cdot \mathrm{cm}^{-3}$ less than that at lower level $(-0.25 \mathrm{~m}$, Figure $2 \mathrm{a})$. Nevertheless, soil moisture at the two layers follow each other closely throughout the year with generally high values in winter and spring and low values from July (from Day 190) until the end of fall (Day 300). Nevertheless, the general seasonal trend is frequently interrupted by precipitation events. Winter snowfall and spring snowmelt increases soil moisture, while dry summer conditions lead to greater evaporation and thus reduce soil moisture. Furthermore, in the dry season, both levels have similar soil moisture which is less than $0.25 \mathrm{~cm}^{3} \cdot \mathrm{cm}^{-3}$.

Similar to $\mathrm{T}_{\text {skin }}$ (shown in Figure 1), $\mathrm{T}_{\text {soil }}$ at the upper level $(-0.05 \mathrm{~m})$, middle level $(-0.15 \mathrm{~m})$ and lower level $(-0.25 \mathrm{~m})$ have a similar annual cycle, with the peak in summer and minimum in winter following the seasonal cycle of solar radiation (Figure 2b). Over the Lamont site, the minimum soil temperature is about $-3.0{ }^{\circ} \mathrm{C}$ in December and January, and then almost linearly increases to a July maximum of $32.3{ }^{\circ} \mathrm{C}$. In addition, in summer the upper level soil temperature is higher than that of the lower level due to heat transport from the surface, but an opposite pattern is found in winter due to surface radiative cooling. 
Figure 2. (a) Annual variations of daily averaged soil moisture at upper layer $(-0.05 \mathrm{~m})$ and lower layer $(-0.25 \mathrm{~m})$. (b) Annual variation of daily averaged soil temperature for upper soil layer $(-0.05 \mathrm{~m})$, middle soil layer $(-0.15 \mathrm{~m})$ and lower soil layer $(-0.25 \mathrm{~m})$.

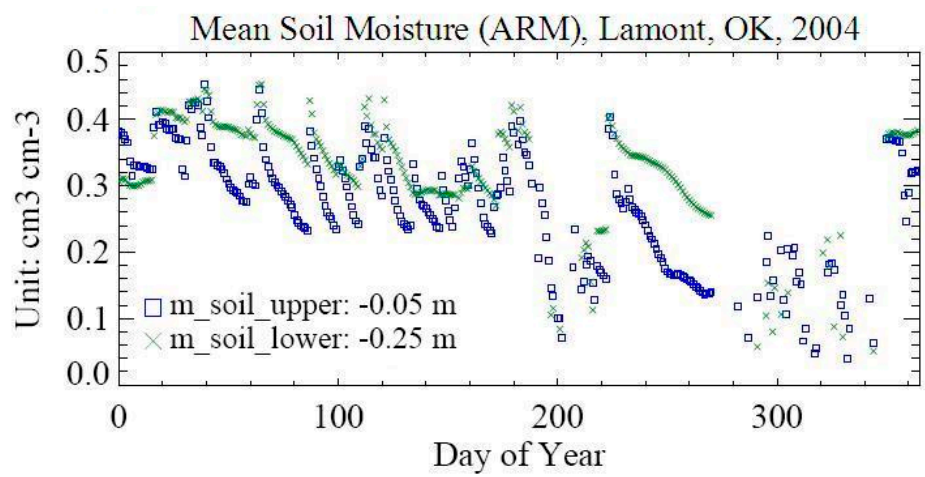

(a)

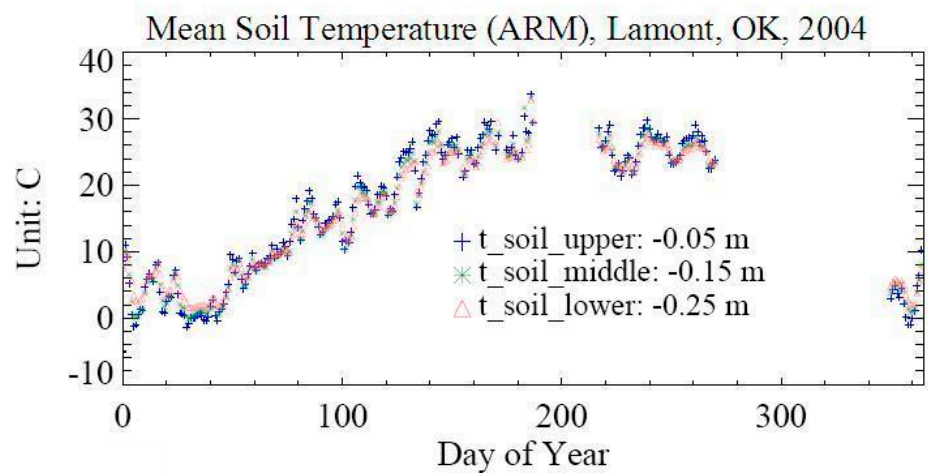

(b)

Figure 3. Soil temperature and skin temperature relations based on annual daily averaged ARM observation at Lamont OK site. (a) upper soil temperature vs. skin temperature, and (b) lower soil temperature vs. skin temperature. Data is daily mean during 2004.

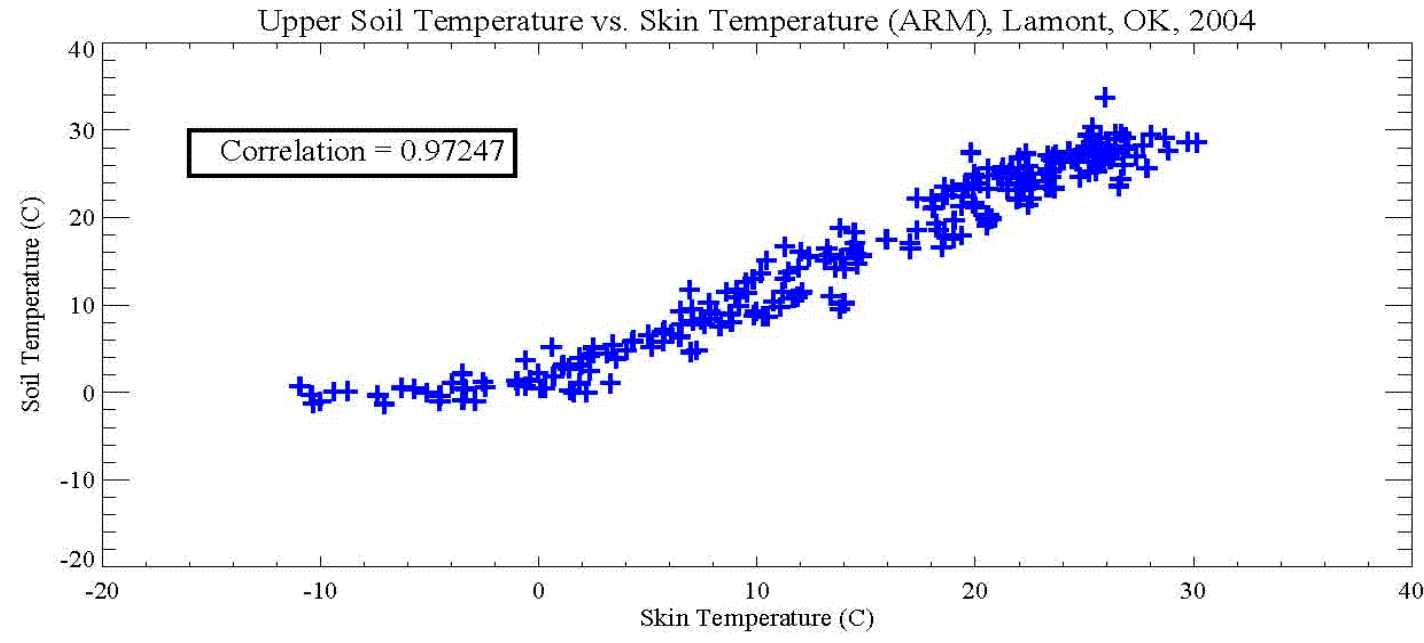

(a) 
Figure 3. Cont.

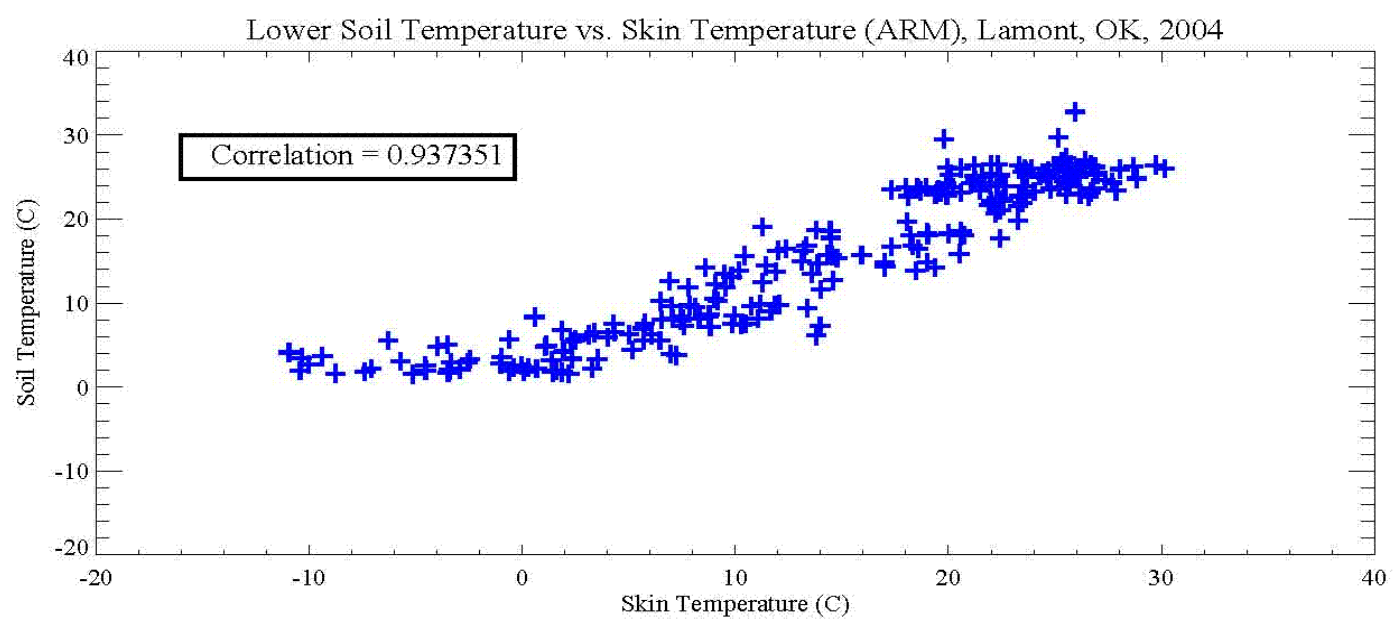

(b)

$\mathrm{T}_{\text {soil }}$ correlates highly with $\mathrm{T}_{\text {skin }}$ (Figure 3 ) because of the heat propagation from ground to soil. Sampled for the year 2004, the daily averaged upper $\mathrm{T}_{\text {soil }}$ and $\mathrm{T}_{\text {skin }}$ has a high correlation coefficient up to 0.97 (Figure 3a), with a value of 0.94 (Figure $3 \mathrm{~b}$ ) for lower $\mathrm{T}_{\text {soil }}$ and $\mathrm{T}_{\text {skin. }}$. This suggests that the upper level $\mathrm{T}_{\text {soil }}$ is more closely related to $\mathrm{T}_{\text {skin }}$ because the absorbed surface insolation is partly used to warm the ground and partly transported in terms of ground heat flux to warm soil. More importantly, the close-to-linear relationship between $\mathrm{T}_{\text {skin }}$ and $\mathrm{T}_{\text {soil }}$ as well as for $\mathrm{T}_{\text {air }}$ and $\mathrm{T}_{\text {soil }}$ may be useful for predicting these two temperatures. Correlation coefficient of 0.97 for daily mean $\mathrm{T}_{\text {skin }} v s$. $\mathrm{T}_{\text {soil }}$ only means that these two parameters are highly related, but it is not linear. Furthermore, the almost flat $\mathrm{T}_{\text {soil }}$ when $T_{\text {skin }}$ is below 0 , which means that when the surface is frozen, the soil temperature at particular layer varies little.

In contrast, soil moisture does not correlate well with $\mathrm{T}_{\text {skin }}$ (not shown). Specifically, a negative correlation coefficient $(-0.42, p$-value $=0.05)$ is detected between the upper level soil moisture and $\mathrm{T}_{\text {skin. }}$. This low negative correlation coefficient is because $\mathrm{SH}$ and LE are competing physical processes to re-distribute the surface absorbed radiative energy. Nevertheless, the low coefficients reveal the loose relationship between these two parameters.

The phase lag in the diurnal variations of temperature (Figure 4) at different layers $-2-m \mathrm{~T}_{\text {air }}, \mathrm{T}_{\text {skin }}$, and $\mathrm{T}_{\text {soil }}$ at upper, middle, and lower levels, respectively, show evident energy propagation among air-land-soil. In January (Figure $4 \mathrm{a}$ ), $\mathrm{T}_{\text {skin }}$ has the largest diurnal variation because the skin level (e.g., ground at this location) absorbs surface insolation most rapidly. $\mathrm{T}_{\text {air }}$ has a smaller diurnal range than $\mathrm{T}_{\text {skin }}$ but a larger diurnal range than the upper, middle, and lower layers $\mathrm{T}_{\text {soil. }}$. The upper layer $\mathrm{T}_{\text {soil }}$ has larger variations than the middle and lower layers $\mathrm{T}_{\text {soil }}$. In fact, not much diurnal variation occurs at the low soil layer $(-0.25 \mathrm{~m})$, implying that heat can be barely transported to this depth. In addition, the phase lag of diurnal variation is evident: $\mathrm{T}_{\text {skin }}$ reaches its maximum $\left(10.03{ }^{\circ} \mathrm{C}\right)$ at 13:00, then $\mathrm{T}_{\text {air }}$ reaches its maximum $\left(7.17^{\circ} \mathrm{C}\right) 2 \mathrm{~h}$ later $(15: 00)$ after the land surface heats up, while soil layers reach maximum at 16:00 for the upper layer $\left(5.10^{\circ} \mathrm{C}\right), 17: 00$ for the middle layer $\left(4.66^{\circ} \mathrm{C}\right)$, and 23:00 for the upper layer $\left(4.99{ }^{\circ} \mathrm{C}\right)$. Furthermore, the minima of these temperatures are $-1.46{ }^{\circ} \mathrm{C}(07: 00)$ for $\mathrm{T}_{\text {air }}$, $-2.24{ }^{\circ} \mathrm{C}(07: 00)$ for $\mathrm{T}_{\text {skin, }}, 2.25^{\circ} \mathrm{C}(08: 00)$ for the upper layer soil, $3.63{ }^{\circ} \mathrm{C}$ (12:00) for the middle layer soil, and $4.48{ }^{\circ} \mathrm{C}(11: 00)$ for the lower layer soil. Note that in winter, soil layers are warmer than both 
air and ground with deeper soils being warmer than upper soils. Radiative cooling near the ground is very clear at night, leading to lower $\mathrm{T}_{\text {skin }}$ than $\mathrm{T}_{\text {air }}$ and $\mathrm{T}_{\text {soil }}$.

Figure 4. Multi-year (2003-2008) averaged diurnal variations of 2-m air temperature $\left(\mathrm{T}_{\text {air }}\right)$, skin temperature $\left(\mathrm{T}_{\text {skin }}\right)$, and soil temperature at upper level ( $-0.05 \mathrm{~m}$ from ground), Middle level $(-0.15 \mathrm{~m})$ and Lower level $(-0.25 \mathrm{~m})$ for (a) January and (b) July.

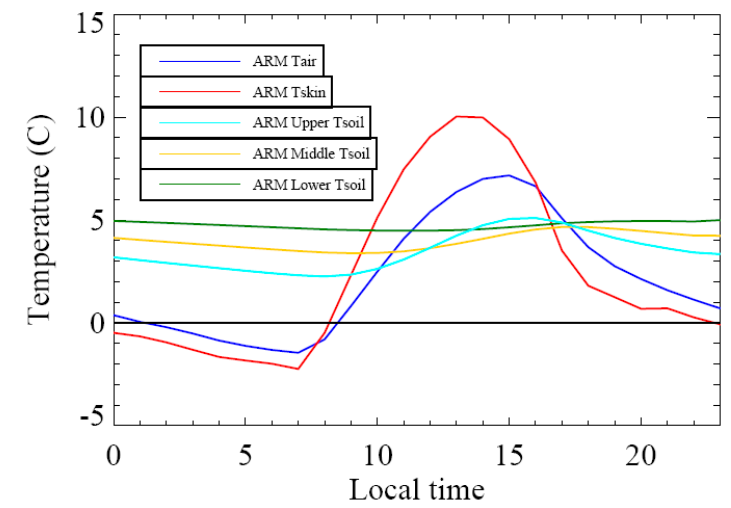

(a)

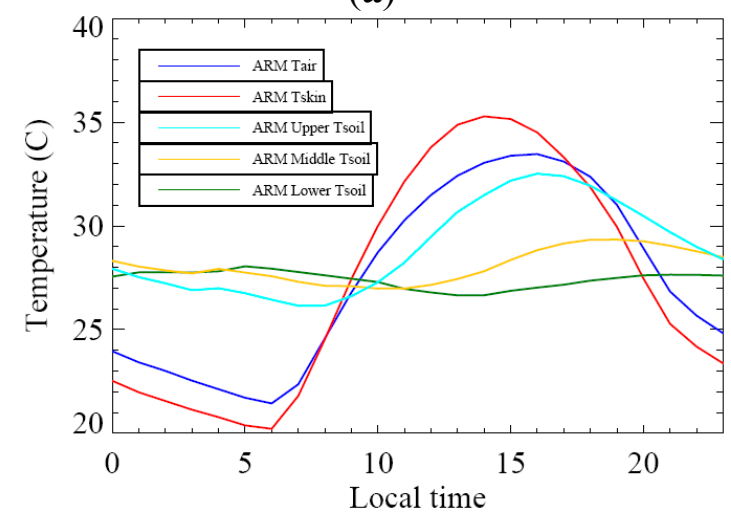

(b)

In July (Figure 4b), the diurnal maxima are $33.46{ }^{\circ} \mathrm{C}(16: 00)$ for $\mathrm{T}_{\text {air }}, 35.28{ }^{\circ} \mathrm{C}(14: 00)$ for $\mathrm{T}_{\text {skin, }}$, and $32.52{ }^{\circ} \mathrm{C}$ (16:00), $29.34{ }^{\circ} \mathrm{C}$ (19:99), and $28.05{ }^{\circ} \mathrm{C}$ (05:00) for upper, middle, and lower $\mathrm{T}_{\text {soill }}$, respectively. The minimum for the upper layer $\mathrm{T}_{\text {soil }}$ is $26.15{ }^{\circ} \mathrm{C}(07: 00)$, while it is $26.98{ }^{\circ} \mathrm{C}(10: 00)$ and $26.65{ }^{\circ} \mathrm{C}(13: 00)$ for the middle and lower layers, respectively. In addition, $\mathrm{T}_{\text {skin }}$ has a larger diurnal variation $\left(15.07{ }^{\circ} \mathrm{C}\right)$ than $\mathrm{T}_{\text {air }}\left(12.02{ }^{\circ} \mathrm{C}\right)$. More importantly, the upper $\mathrm{T}_{\text {soil }}$ has much more significant diurnal range $\left(6.37^{\circ} \mathrm{C}\right)$ than in January, and other soil layers show little variation $\left(2.36^{\circ} \mathrm{C}\right.$, $1.0{ }^{\circ} \mathrm{C}$ ). In fact, the lower $\mathrm{T}_{\text {soil }}$ shows an inverse pattern, namely, a maximum in the morning and minimum in the afternoon. Furthermore, $T_{\text {skin }}$ and $T_{\text {air }}$ both reach minimum at the same time (6 AM), with values of $20.21{ }^{\circ} \mathrm{C}$ for $\mathrm{T}_{\text {skin }}$ and $21.44{ }^{\circ} \mathrm{C}$ for $\mathrm{T}_{\text {air. }}$ In July (Figure $4 \mathrm{~b}$ ), $\mathrm{T}_{\text {soil }}$ at the lower level $(-0.25 \mathrm{~cm})$ still has diurnal variation due to the arrival of heat propagated from surface. Nevertheless, it takes about $10 \mathrm{~h}$ for heat to reach this level, and thus $\mathrm{T}_{\text {soil }}$ of this layer has a clear opposite phase than $\mathrm{T}_{\text {skin }}$ diurnal cycle. In January (Figure $4 \mathrm{a}$ ), however, little heat can be transported into this level due to frozen ground, and thus no clear diurnal cycle at this soil layer.

Based on the 6-year (2003-2008) annual diurnal cycle, $\mathrm{T}_{\text {air }}$ is more closely related to the upper layer $\mathrm{Ts}_{\text {oil }}$ than $\mathrm{T}_{\text {skin }}$ (Table 1). For example, in January, the correlation coefficient between $\mathrm{T}_{\text {air }}$ and upper $\mathrm{T}_{\text {soil }}$ is 0.87 and only 0.64 for $\mathrm{T}_{\text {skin }} v s$. upper $\mathrm{T}_{\text {soil. }}$ Similarly, $\mathrm{T}_{\text {air }} v s$. the middle layer $\mathrm{T}_{\text {soil }}$ has a higher 
correlation coefficient $(0.41)$ than that between $\mathrm{T}_{\text {skin }} v s$. the middle layer $\mathrm{T}_{\text {soil }}(0.07)$. On the contrary, the lower layer $\mathrm{T}_{\text {soil }}$ has a higher but negative correlation with $\mathrm{T}_{\text {skin. }}$. Specifically, the coefficient between $T_{\text {skin }}$ and the lower layer $T_{\text {soil }}$ in January is -0.53 but -0.26 between $T_{\text {air }}$ and the lower layer $\mathrm{T}_{\text {soil }}$ for the same month. More importantly, seasonality is very clear: In July, both $\mathrm{T}_{\text {air }}$ and $\mathrm{T}_{\text {skin }}$ have a much higher correlation with the lower layer $\mathrm{T}_{\text {soil }}$ than in January. While in July, $\mathrm{T}_{\text {skin }} v s$. lower $\mathrm{T}_{\text {soil }}$ is -0.93 and for January it is only -0.54 . This is probably because lower $\mathrm{T}_{\text {soil }}$ has little diurnal variation, but the minimum value is in the afternoon, and maximum in the morning (opposite of normal diurnal cycle, as noticed in Figure 4b).

Table 1. Correlation Coefficients based on 2003-2008 monthly mean observations. The correlation coefficients are based on hourly-averaged temperatures for each day of the month between 2003-2008 $(n=4644)$.

\begin{tabular}{lcccc}
\hline & $\mathbf{T}_{\text {air }}$ January & $\mathbf{T}_{\text {skin }}$ January & $\mathbf{T}_{\text {air }} \mathbf{J u l y}$ & $\mathbf{T}_{\text {skin }} \mathbf{J u l y}$ \\
\hline Upper $\mathrm{T}_{\text {soil }}$ & 0.8707 & 0.6431 & 0.8842 & 0.8023 \\
Middle $\mathrm{T}_{\text {soil }}$ & 0.4165 & 0.0753 & 0.2978 & 0.1231 \\
Lower $\mathrm{T}_{\text {soil }}$ & -0.2614 & -0.5396 & -0.8795 & -0.9382 \\
$\mathrm{~T}_{\text {skin }}$ & 0.9327 & - & 0.9831 & - \\
\hline
\end{tabular}

Note that $T_{\text {skin }}$ and upper $T_{\text {soil }}$ have a 0.97 correlation (Figure 3a) while it is only 0.80 for July and 0.63 for January in Table 1 . This is probably because Table 1 is based on the multi-year averaged diurnal cycle for 2003-2008, namely, an average over all days to get a diurnal cycle for the month, and then averaged over all years. Furthermore, Table 1 represents the inter-annual variations of the variable.

Autocorrelation presents self-persistency of a variable. Soil temperatures have the highest autocorrelations with day lag (Figure 5a). The deeper the soil, the greater the self-persistency is as reflected in the autocorrelation coefficients. In addition, the lag autocorrelation for soil moisture decreases faster than other variables, implying the least self-persistency among these parameters. Furthermore, the upper layer soil moisture has less self consistency than the lower soil moisture after one day.

Cross-correlation with day lag (Figure $5 b$ ) shows that $T_{\text {skin }}$ and the upper layer $T_{\text {soil }}$ have the highest cross-correlation ( $\sim 0.90)$, and that cross-correlation increases with depth, namely, higher correlation of $\mathrm{T}_{\text {skin }}$ with the middle and lower layers $\mathrm{T}_{\text {soil }}$ than $\mathrm{T}_{\text {skin }}$ with the upper layer $\mathrm{T}_{\text {soil. }}$ In addition, $\mathrm{T}_{\text {skin }}$ and $\mathrm{T}_{\text {air }}$ have relatively low cross-correlations, from 0.96 at a day lag of 1 dropping to 0.8 at a day lag of 5 . Furthermore, the upper layer soil moisture and the lower layer soil moisture have the lowest positive cross-correlation, and this value rapidly decreases as day lag increases. Again, $\mathrm{T}_{\text {soil }}$ and soil moisture have a negative cross-correlation, of around -0.6 at a day of lag 1 and remaining mostly unchanged as day lag increases. 
Figure 5. (a) Autocorrelation with day lag using daily averaged data from 2003-2008 data. $\mathrm{T}_{\text {air }}$ is $2-\mathrm{m}$ air temperature. $\mathrm{T}_{\text {skin }}$ is skin temperature. $\mathrm{T}_{\text {soilup }}$ is upper soil temperature. $\mathrm{T}_{\text {soilmid }}$ is middle layer soil temperature. $T_{\text {soillow }}$ is lower layer soil temperature. $M_{\text {soilup }}$ and $M_{\text {soillow }}$ are upper and low soil moisture, respectively. (b) Cross-correlation with day lag.

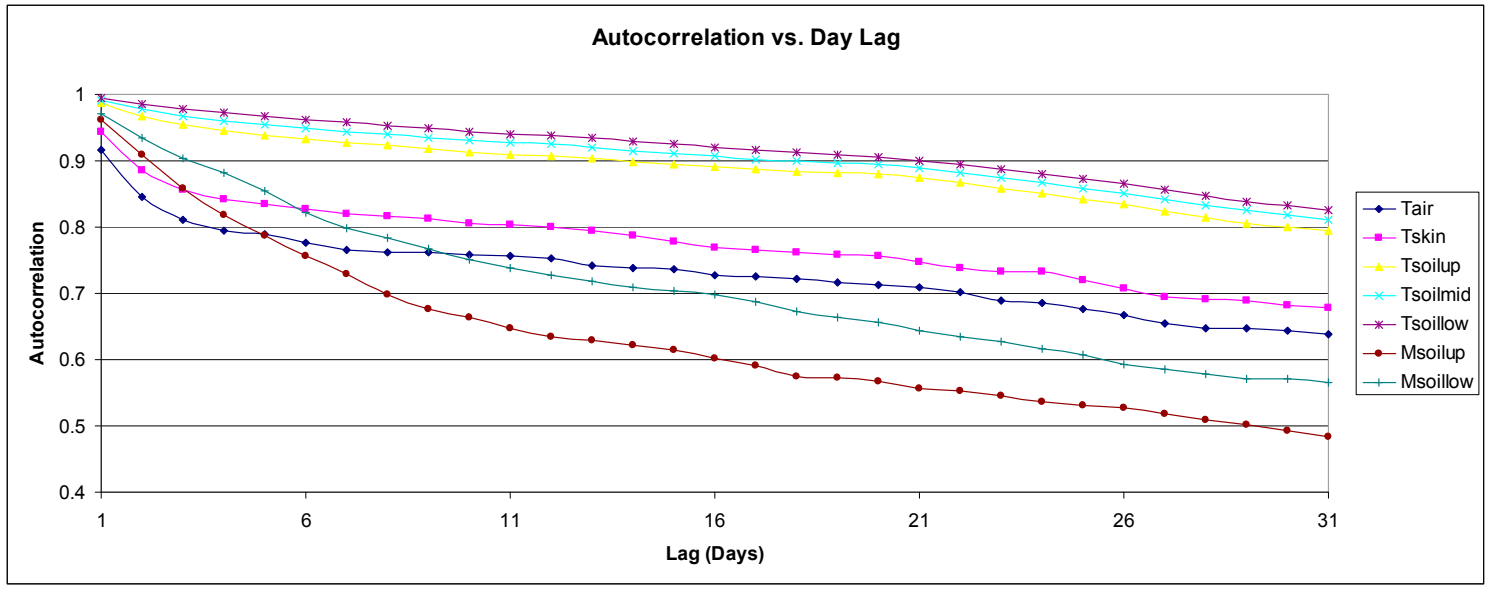

(a)

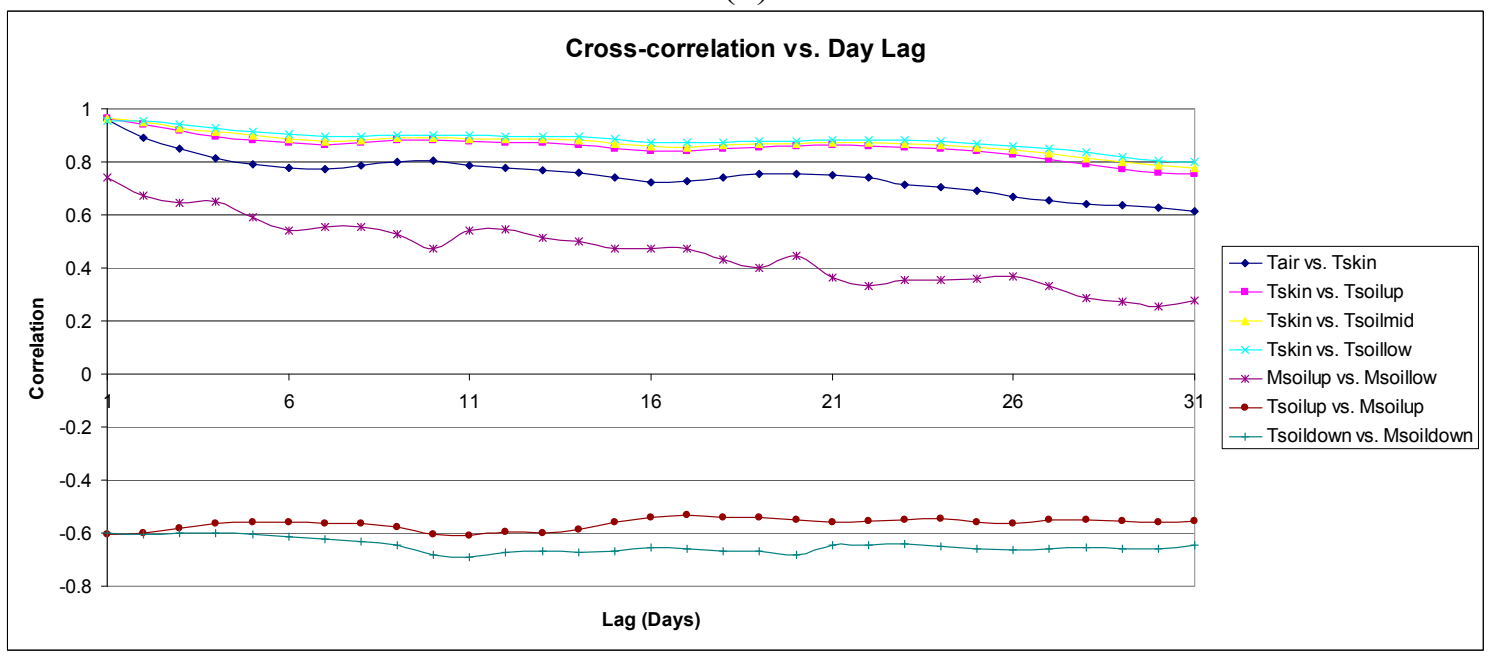

(b)

\subsection{CLM4 Simulations}

Soil moisture simulations in CLM4 do not get the absolute values correct, but well simulate the peaks, partly because the model responds to rainfall in the atmospheric forcing data (Figure 6). Specifically, in the model layer 3 (comparable to ARM upper layer $-0.05 \mathrm{~m}$, Figure $6 \mathrm{a}$ ), soil moisture values are systematically lower than the observations, revealing that the model is too dry at this layer. Once rainfall events occur, however, the soil moisture in the model is close to observations as a result of the model's response to rainfall forcing. From then, the model soil moisture drops quickly from rainfall-induced peaks and the modeled values are apart from the observations by about 0.10 $\mathrm{mm}^{3} \cdot \mathrm{mm}^{-3}$ (e.g., $0.40 \mathrm{~mm}^{3} \cdot \mathrm{mm}^{-3}$ in day 50 but $0.30 \mathrm{~mm}^{3} \cdot \mathrm{mm}^{-3}$ in CLM4). This suggests that the model loses soil moisture too quickly at this layer. Further analysis implies that one possible reason for this is the large latent heat flux in the model at the ground which reduces soil moisture too quickly from lower soil layers. The averaged root-mean-square error (rms) is $0.04 \mathrm{~mm}^{3} \cdot \mathrm{mm}^{-3}$ and the 
ARM-forced run has relatively larger rms than the control run does, which is unexpected because the ARM-forced run has soil moisture spin up, accurate solar radiation, and rainfall from observations in the forcing. At the lower layer ( $-0.25 \mathrm{~m}$, comparable to model layer 5, Figure 6b), CLM4 simulated soil moisture is lower than the observations in spring (Julian days 1-120); therefore, the model is still dryer than the observations during this period of time. However, during summer (Julian days 121-180), model simulated soil moisture in general is higher than the observations. Namely, model lower layer is wetter than the observations in summer. In addition, one problem identified is that the model soil moisture is lower than the observation from the very first day (day 0). Since the CLM4 ARM-forced run has soil moisture spin up, the modeled soil moisture should be close to the ARM observation at least at the beginning as day 0-5 in layer 3 (Figure 6a). Further analysis reveals that while CLM4 has default saturation soil moisture and even spin-up soil moisture is close to the observation, the model replaces the spin up soil moisture using the default saturation value. The problem may also explain why, soon after a rainfall event, CLM4 soil moisture increases to close to observation value, but keeps dropping to $0.30 \mathrm{~mm}^{3} \cdot \mathrm{mm}^{-3}$. Note that Figure 6 only shows spring and summer because in fall and winter, soil moisture is frozen and causes problems in the ARM observations. Furthermore, the very similar results in the control run and the ARM-forced run suggest that the model has a problem in its soil moisture. Nevertheless, when the forcing has rainfall, it brings the modeled soil moisture value close to the observations. This means that the forcing is important. The better the forcing, the better the model results.

Examining the correlation of soil moisture between the upper layer and lower layers reveals the dependency and vertical structure of soil moisture. In ARM, the correlation coefficient of soil moisture at these two layers is only 0.64 (Figure 7a) while in CLM4, this correlation coefficient is 0.96 (Figure 7b). Therefore, ARM data are very scattered (Figure 7a) but CLM values are very close to each other (Figure $7 \mathrm{~b}$ ). In addition, the range of soil moisture for layer 5 is $0.30-0.48 \mathrm{~mm}^{3} \cdot \mathrm{mm}^{-3}$ in ARM data while it is only $0.20-0.42 \mathrm{~mm}^{3} \cdot \mathrm{mm}^{-3}$ in CLM4. In conclusion, two weaknesses are identified here for CLM4: First, in the model, in terms of soil moisture, model layers are too tightly coupled; and second, at the lower layer, soil moisture is too low and the range is too small $\left(0.25-0.40 \mathrm{~mm}^{3} \cdot \mathrm{mm}^{-3}\right.$ in CLM4 while ARM data is $0.18 \mathrm{~mm}^{3} \cdot \mathrm{mm}^{-3}$ ).

Similar to Figure 3, CLM4 shows the high correlation between soil temperature and $\mathrm{T}_{\text {skin }}$ (Figure 8). The correlation coefficients on daily averaged soil temperature and $\mathrm{T}_{\text {skin }}$ are 0.99 for upper layer and 0.97 for lower layer. Comparing this with the ARM observations where correlation coefficients are 0.97 for the upper layer and 0.94 for the lower layer (Figure 3), CLM4 has slightly higher dependence between soil temperature and $\mathrm{T}_{\text {skin }}$ than the ARM observations. The overall relation is well simulated by the model.

Similar to the ARM observations (Figure 2b), soil temperatures in CLM4 Layers 3, 4 and 5 are very close to each other (Figure 9). Apparently, all three layers have the same seasonality because the surface insolation is the key factor determining soil temperature. Nevertheless, layer $3(-0.05 \mathrm{~m})$ has larger temperature variations than the other two underlying soil layers, as expected. For example, around Julian day $40, \mathrm{~T}_{\text {soil }}$ for layer 3 is $2-3{ }^{\circ} \mathrm{C}$ lower than that of layer 4 and 5 , but around Julian day 200 , it is higher than the other two layers by about $2{ }^{\circ} \mathrm{C}$. Such larger seasonality and daily variation are partly due to stronger ground heat flux transport between surface and the upper soil layer and partly due to the fact that model is too dry at this layer, as revealed in Figure 6a. 
Figure 6. Simulated daily averaged volumetric soil moisture from offline community land model (CLM4) in (a) the upper layer (layer 3, $-0.05 \mathrm{~m}$ ) and (b) the lower layer (Layer 5, $-0.3 \mathrm{~m}$ ). The control run (CLM4-control) is forced by the default atmospheric forcing provided by National Center for Atmospheric Research (NCAR) model release package and the ARM-forced run (CLM-ARM-forced) uses the hourly ARM observed atmospheic forcing data in Year 2004.

(a) Layer 3: $0.05 \mathrm{~m}$, rms control $=0.037$, arm-forcing $=0.041$

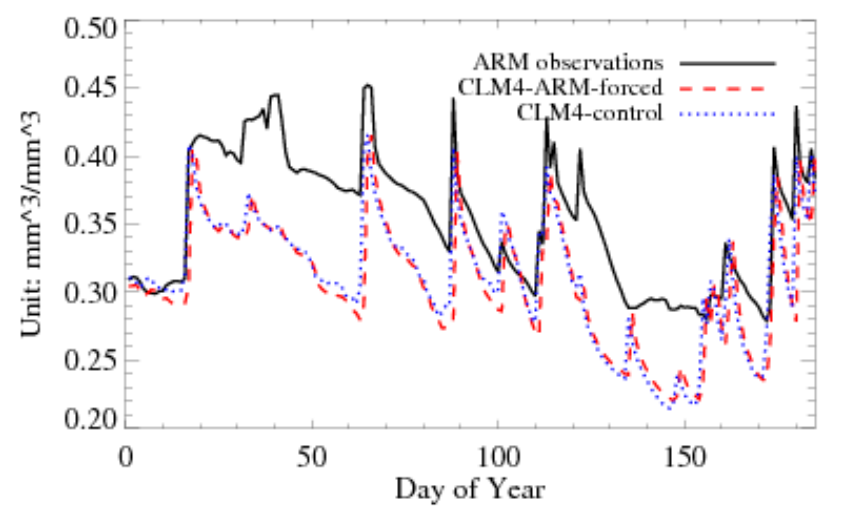

(b) Layer 5: $0.25 \mathrm{~m}$, rms: control $=0.029$, arm-forcing $=0.033$

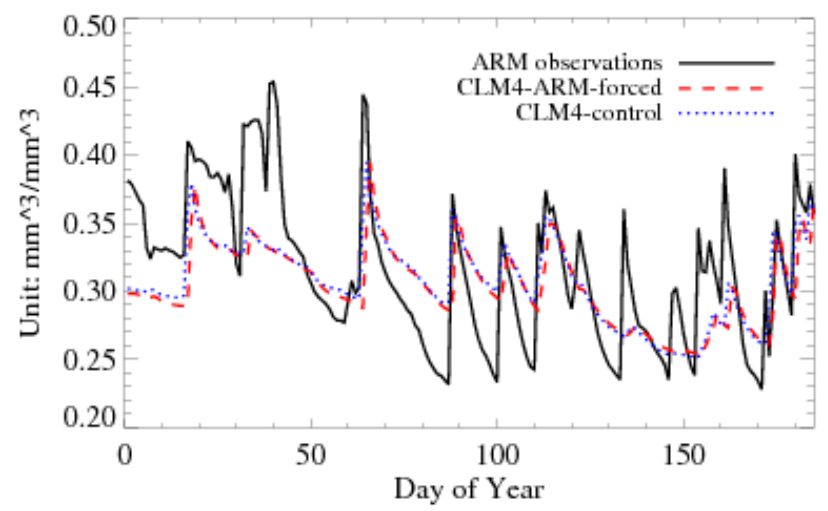

The diurnal phase of 2-m $\mathrm{T}_{\text {air }}, \mathrm{T}_{\text {skin, }}$ and $\mathrm{T}_{\text {soil }}$ are well simulated in offline CLM4 (Figure 10), comparing those to ARM observations (Figure 4). First, $\mathrm{T}_{\text {skin }}$ is lower than $\mathrm{T}_{\text {air }}$ at night but warmer than $\mathrm{T}_{\text {air }}$ during daytime after sunrise, a feature consistent with many previously studies [15]. Second, $\mathrm{T}_{\text {soil }}$ in layer 3 is lower than $\mathrm{T}_{\text {skin }}$ with $3 \mathrm{~h}$ time lag because heat is propagated from the surface skin layer into the ground. Furthermore, the lower layer $\mathrm{T}_{\text {soil }}(-0.25 \mathrm{~m})$ has the opposite phase to $\mathrm{T}_{\text {skin }}$ and $\mathrm{T}_{\text {air }}$ in both January and July, namely, high at local night but low at local daytime. Another deficiency in the model is that $\mathrm{T}_{\text {soil }}$ is higher than Tair in July 2004 (Figure 10b), which is not found in the ARM data (Figure 4b). Nevertheless, the most evident deficiency between the CLM4 and the ARM observations occur at nighttime on $\mathrm{T}_{\text {skin }}$ and $\mathrm{T}_{\text {air }}$. In the real world (Figure 4 ), $\mathrm{T}_{\text {skin }}$ is lower than $\mathrm{T}_{\text {air }}$ by about $0.5^{\circ} \mathrm{C}$ to $2{ }^{\circ} \mathrm{C}$ in January and July, respectively. However, in the model, these two temperatures are too close at nighttime because $\mathrm{T}_{\text {skin }}$ is too high. Since in an offline model run, $\mathrm{T}_{\text {air, }}$ downward longwave radiation, and wind are all from the observed ARM observations, this nighttime deficiency suggests some model problems which lead to a hot skin surface in CLM4. In addition, the diurnal scale peak of July $\mathrm{T}_{\text {skin }}$ is higher in CLM4 than in the observations. 
Figure 7. Correlation of volumetric soil moisture between the upper and lower layers: (a) is the ARM observations and (b) is the CLM simulations. Data is daily average for year 2004.

(a) ARM Observation, r(layer 3, layer 5) $=0.64$

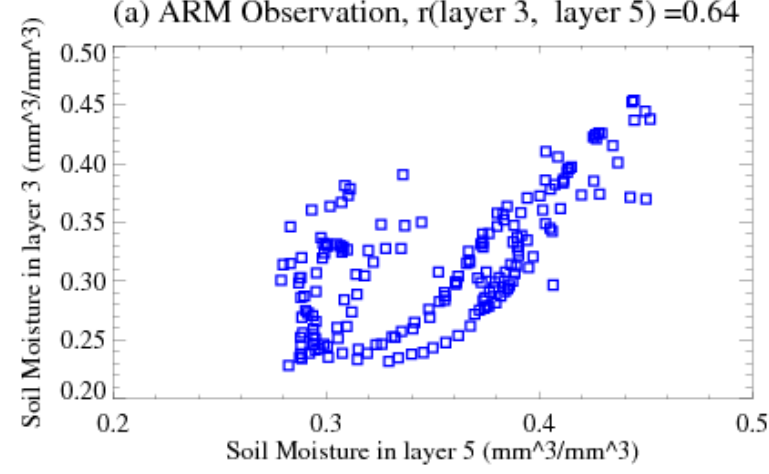

(b) CLM4 simulation, $r($ layer 3, layer 5) $=0.96$

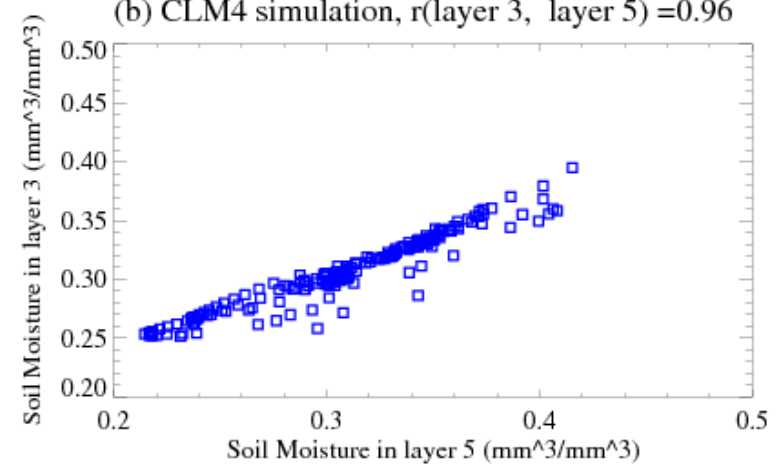

Figure 8. Same as Figure 3, except that skin temperature and soil moisture are from offline CLM4 ARM-forced run for daily averaged value in Year 2004, (a) the upper soil layer $(-0.05 \mathrm{~m})$ and $(\mathbf{b})$ the lower soil layer $(-0.25 \mathrm{~m})$.
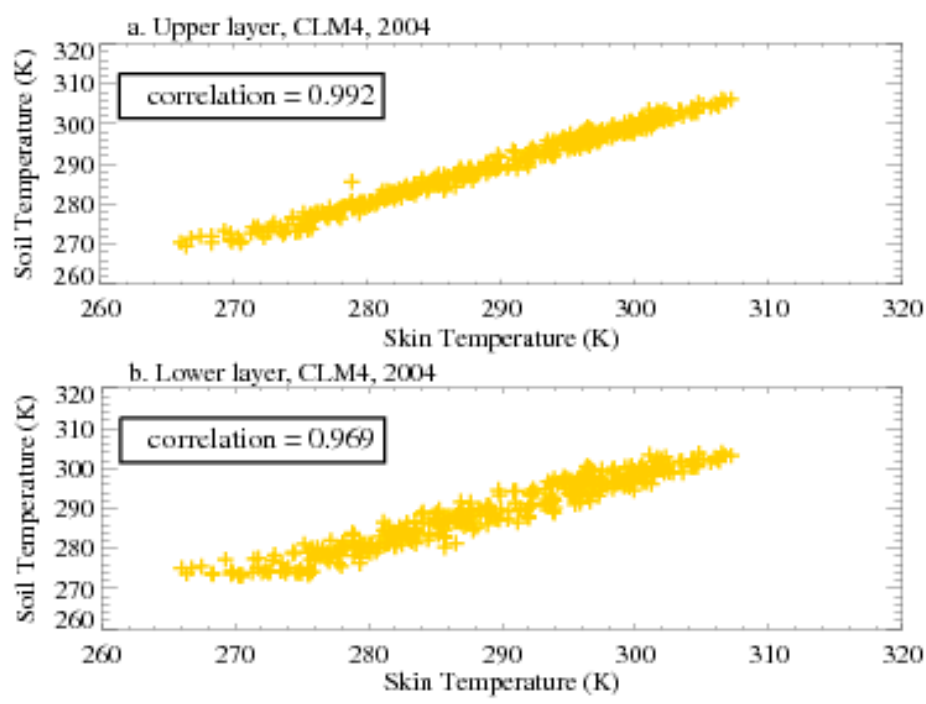
Figure 9. Offline CLM4 simulated daily averaged soil temperature at the upper soil layer (model layer 3, $-0.05 \mathrm{~m}$ ), the middle layer (model layer $4,-0.12 \mathrm{~m}$ ) and the lower layer (model layer $5,-0.25 \mathrm{~m}$ ). The model run uses ARM hourly atmospheric forcing for Year 2004.

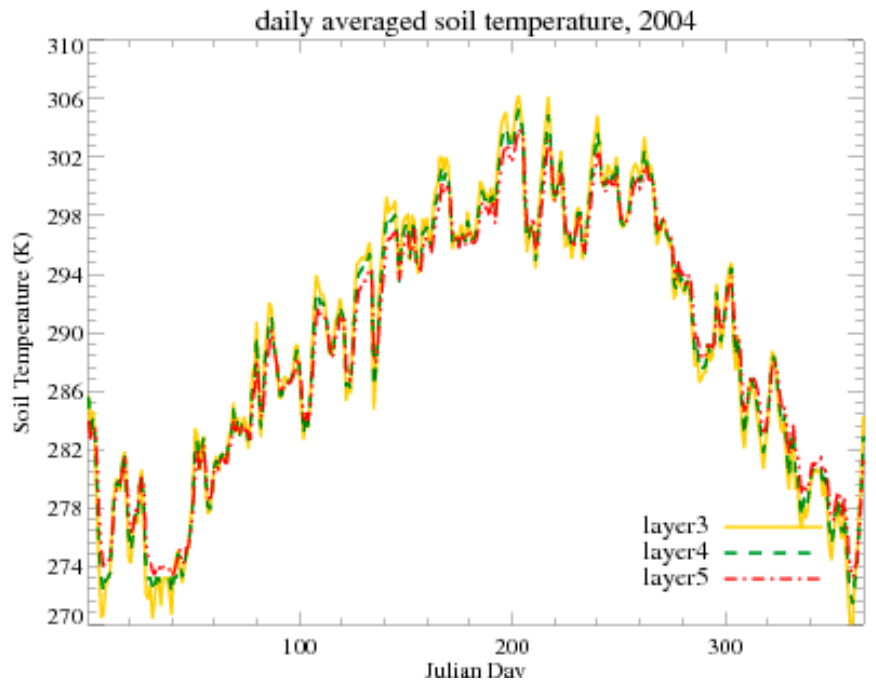

Figure 10. CLM4 simulated monthly mean $T_{\text {skin, }}, T_{\text {air }}, T_{\text {soil }}$ at the upper soil layer $\left(T_{\text {soil3 }}\right)$ and $T_{\text {soil }}$ at the lower soil layer ( $T_{\text {soils }}$ ) for (a) January 2004 and (b) July 2004. The model run is forced by ARM hourly observations.

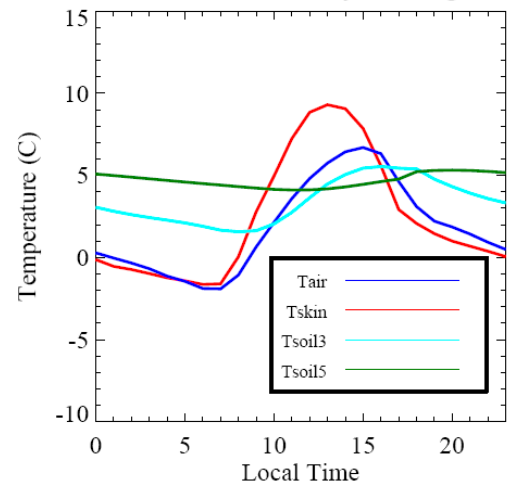

(a)

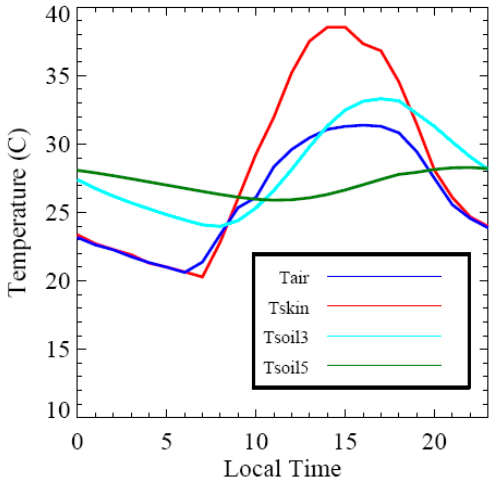

(b)

\section{Final Remarks}

As the key parameters in a land surface model, vertical distribution of soil moisture and soil temperature show evident relations between skin and air temperatures. New findings of this work include:

a. At different scales, the signals of these variables are different. For example, at the daily scale, $\mathrm{T}_{\text {skin }}$ and $\mathrm{T}_{\text {soil }}$ have high correlation coefficients of up to 0.97 . However, on an annual diurnal cycle scale, the correlation between $\mathrm{T}_{\text {skin }}$ and upper $\mathrm{T}_{\text {soil }}$ correlation is only 0.64 for January and 0.84 for July. This means that the features of $\mathrm{T}_{\text {skin }}, \mathrm{T}_{\text {air }}, \mathrm{T}_{\text {soil }}$, and soil moisture need very high temporal monitoring in order to realistically understand the variations and mechanisms of these changes. 
b. The lower layer $\mathrm{T}_{\text {soil }}(-0.25 \mathrm{~m})$ has a negative correlation with $\mathrm{T}_{\text {skin }}$ and $\mathrm{T}_{\text {air }}$ at the diurnal cycle scale. Specifically, at $-0.25 \mathrm{~m}$ of this specific location, $\mathrm{T}_{\text {soil }}$ does not vary much with the seasonality of surface insolation. CLM4 reproduces these correctly.

c. $\mathrm{T}_{\text {air }}$ has a higher correlation with the upper soil layer $\mathrm{T}_{\text {soil }}$ because both $\mathrm{T}_{\text {air }}$ and upper $\mathrm{T}_{\text {soil }}$ need time to be heated up after $\mathrm{T}_{\text {skin }}$ increases. Therefore, the thermal inertial at the air layer and upper soil layer needs to be considered in the model to reproduce the time lag in heating up. CLM4 simulates this feature well.

d. $T_{\text {soil }}$ has higher self-consistency than $\mathrm{T}_{\text {skin }}$ and $\mathrm{T}_{\text {air }}$. $\mathrm{T}_{\text {skin }}$ has a slightly higher self-consistency than $\mathrm{T}_{\text {air. }}$. This may also be explained by the different heat capacity of soil, surface, and air.

e. Soil moisture is closely controlled by precipitation events. Soil moisture and $\mathrm{T}_{\text {skin }}$ have a negative correlation since more soil moisture leads to more absorbed radiative energy redistributed into latent heat flux instead of sensible heat flux

f. Although CLM4 is capable of simulating the relations of $T_{\text {skin }}, T_{\text {soil }}$, and moisture reasonably well, a few critical deficiencies are identified: First, CLM4 is too dry at both upper and lower soil layers. Second, CLM4 shows too much dependency between moisture on different layers. Third, nighttime $\mathrm{T}_{\text {skin }}$ is $0.5-2.0{ }^{\circ} \mathrm{C}$ higher than the observations. This nighttime deficiency suggests some model problems which lead to a hot skin surface in CLM4. However, to be more explicit: further research is needed in order to determine whether the error is in the soil transfer or upward longwave or emissivity.

One important finding from this work is that high quality, high temporal resolution observations are needed to understand the highly heterogeneous parameters of the land surface soil moisture. In addition, good atmospheric forcing is critical in order to evaluate the land model in offline mode.

\section{Acknowledgements}

This work is supported by NSF larger-scale dynamics program. We thank Marc Fischer for discussion on his CO2flx data and editing the manuscript. The data used in this study were collected by the Atmospheric Radiation Measurement Program Southern Great Plains facility, operated by the Office of Biological and Environment research within the U.S. Department of Energy.

\section{Author Contributions}

The authors contributed equally to this work.

\section{Conflicts of Interest}

The authors declare no conflict of interest.

\section{References}

1. Wu, W.; Dickinson, R.E. Time scales of layered soil moisture memory in the context of land-atmosphere interaction. J. Clim. 2004, 17, 2752-2764.

2. Betts, A.K.; Silva Dias, M.A.F. Progress in understanding land-surface-atmosphere coupling over the Amazon: A review. J. Adv. Model. Earth Syst. 2010, 2, doi:10.3894/JAMES.2010.2.6. 
3. Alfaro, E.J.; Gershunov, A.; Cayan, D. prediction of summer maximum and minimum temperature over the central and western United States: The roles of soil moisture and sea surface temperature. J. Clim. 2006, 19, 1407-1421.

4. Dirmeyer, P.A. Using a global soil wetness dataset to improve seasonal climate simulation. J. Clim. 2000, 13, 2900-2922.

5. Dickinson, R.E. How coupling of the atmosphere to ocean and land helps determine the timescales of interannual variability of climate. J. Geophys. Res. 2000, 105, 20115-20119.

6. Koster, R.D.; Suarez, M.J. Relative contributions of land and ocean processes to precipitation variability. J. Geophys. Res. 1995, 100, 13775-13790.

7. Koster, R.D.; Suarez, M.J. Soil moisture memory in climate models. J. Hydrometeor. 2001, 2, 558-570.

8. Pal, J.S.; Eltahir, E.A.B. Pathways relating soil moisture conditions to future summer rainfall within a model of the land-atmosphere system. J. Clim. 2001, 14, 1227-1242.

9. Hall, D.K.; Riggs, G.A. Accuracy assessment of the MODIS snow products. Hydrol. Process. 2007, 21, 1534-1547.

10. Jin, M.; Liang, S. Improving land surface emissivity parameter of land surface model in GCM. J. Climate 2006, 19, 2867-2881.

11. Schaaf, C.B.; Gao, F.; Strahler, A.H.; Lucht, W.; Li, X.; Tsang, T.; Strugnell, N.C.; Zhang, X.; Jin, Y.; Muller, J.-P.; et al. First operational BRDF, albedo and nadir reflectance products from MODIS. Remote Sens. Environ. 2002, 83, 135-148.

12. Betts, A.K. Land-surface-atmosphere coupling in observations and models. J. Adv. Model Earth Syst. 2009, 1, doi:10.3894/JAMES.2009.1.4.

13. Jin, M.; Dickinson, R.E.; Vogelmann, A.M. A Comparison of CCM2/BATS skin temperature and surface-air temperature with satellite and surface observations. J. Clim. 1997, 10, 1505-1524.

14. Jin, M.; Dickinson, R.E. Interpolation of surface radiation temperature measured from polar orbiting satellites to a diurnal cycle. Part 1: Without clouds. J. Geophys. Res. 1999, 104, 2105-2116.

15. Jin, M.; Dickinson, R.E. Land surface skin temperature climatology: Benefitting from the strengths of satellite observations. Environ. Res. Lett. 2010, 5, doi:10.1088/1748-9326/5/4/044004.

16. Fischer, M.L.; Billesbach, D.P.; Riley, W.J.; Berry, J.A.; Torn, M.S. Spatiotemporal variations in growing season exchanges of $\mathrm{CO}_{2}, \mathrm{H}_{2} \mathrm{O}$, and sensible heat in agricultural fields of the Southern Great Plains. Earth Interact. 2007, 11, 1-21.

17. Oleson, K.W.; Lawrence, D.M.; Bonan, G.B.; Flanner, M.G.; Kluzek, E.; Lawrence, P.J.; Levis, S.; Swenson, S.C.; Thornton, P.E.; Dai, A.; et al. Technical Description of Version 4.0 of the Community Land Model (CLM). NCAR Technical Note NCAR/TN-478+STR; National Center for Atmospheric Research: Boulder, CO, USA; 2010, p.257.

18. Qian, T.; Dai, A.; Trenberth, K.E.; Oleson, K.W. Simulation of global land surface conditions from 1948 to 2004: Part I: Forcing data and evaluations. J. Hydrometeor. 2006, 7, 953-975.

19. Lawrence, D.M.; Oleson, K.W.; Flanner, M.G.; Thornton, P.E.; Swenson, S.C.; Lawrence, P.J.; Zeng, X.; Yang, Z.-L.; Levis, S.; Sakaguchi, K.; et al. Parameterization improvements and functional and structural advances in version 4 of the Community Land Model. J. Adv. Model. Earth Syst. 2011, 3, doi:10.1029/2011MS000045. 
20. Jin, M.; Terrence, M.; Henry, B. Evaluation offline NCAR CLM4 surface temperature and soil temperature simulations using ARM Lamont observations. J. Clim. 2014, under review.

(C) 2014 by the authors; licensee MDPI, Basel, Switzerland. This article is an open access article distributed under the terms and conditions of the Creative Commons Attribution license (http://creativecommons.org/licenses/by/4.0/). 